\title{
Phlorotannins and related compounds as larval settlement inhibitors of the tube-building polychaete Hydroides elegans
}

\author{
Stanley C. K. Lau*, Pei-Yuan Qian \\ Department of Biology, Hong Kong University of Science and Technology, Clear Water Bay, Kowloon, Hong Kong
}

\begin{abstract}
This study examined the inhibition of Hydroides elegans larval settlement by brown algal phlorotannins as well as 2 related compounds, tannic acid and phloroglucinol. Two mechanisms have been suggested to explain the antifouling effects of natural compounds: natural compounds may target macrofoulers directly, or they may regulate the growth of microfoulers, such as bacteria, which in turn affects larval settlement. We hypothesized that phlorotannins, phloroglucinol and tannic acid inhibit $H$. elegans larval settlement through both mechanisms. In this study, we investigated (1) the $\mathrm{LC}_{50}$ of the 3 compounds on $H$. elegans larvae. (2) the $\mathrm{EC}_{50}$ for inhibition of $H$. elegans larval settlement by the 3 compounds, (3) antibacterial activity of the 3 compounds, and (4) settlement of $H$. elegans larvae on both monospecies and multispecies bacterial films. Twelve different strains of marine bacteria were isolated for antibiosis assays and larval settlement assays. Our results iradicated that phlorotannins, tannic acid, and phloroglucinol were inhibitory to $H$. elegans larval settlement and to the growth of certain marine bacteria. Assays of larval settlement on bacterial films revealed that $H$. elegans larvae settled differentially on different species of bacteria. Changes in either bacterial species or ratio of bacterial species in multispecies bacterial films also affected $H$. elegans larval settlement. An integration of results from the antibiosis assays together with those from the assays of larval settlement on bacterial films revealed that phlorotannins and the related compounds were inhibitory to some of the bacterial species that induced high levels of $H$. elegans larval settlement; however, some of the bacteria that induced low levels of $H$. elegans larval settlement were resistant to the compounds. Therefore, we speculate that the bacteria which induce high level of $H$. elegans larval settlement may be lacking in a biofilm that is developed under the influence of the compounds, and the niches become available to the phenolic-resistant bacteria that cause low levels of $H$. elegans larval settlement. Consequently, the phenolic-treated biofilm may become unfavorable to $H$. elegans larval settlement.
\end{abstract}

KEY WORDS: Hydroides elegans - Natural compounds - Settlement inhibition - Phlorotannins - Bacterial films

\section{INTRODUCTION}

Marine macroalgae provide a vast area of surfaces that are available for larval settlement of marine fouling organisms, yet are rarely fouled. This phenomenon is attributed to the presence of defensive chemicals in the algae (De Nys et al. 1995, Walters et al. 1996). The absence of fouling organisms on brown algae Sargas-

•E-mail: bostan@usthk.ust.hk sum natans is suggested to be due to the presence of phlorotannins (Sieburth \& Conover 1965). Phlorotannins exist exclusively in brown algae and are present in considerable amounts (Ragan \& Glombitza 1986) Phlorotannins are polymerized phloroglucinol $(1,3$, 5 -trihydroxbenzene) and exist in various forms, each of which has different numbers of phloroglucinol and/or different types of links between the phloroglucinol units, such as, aryl-aryl bond (-C-C-) and diaryl ether bond $(-\mathrm{C}-\mathrm{O}-\mathrm{C}-$ ). Phlorotannins are extremely water soluble and enclosed in subcellular structures called 
physodes; they are released continuously from the algae under normal conditions but at an increased rate under stress (Ragan \& Glombitza 1986). It has been shown that phlorotannins exuded from Ralfsia verrucosa into the surrounding environment reduced the survival of barnacle and mussel larvae in tidepools (Conover \& Sieburth 1966) and of other algal species in laboratory culture (Fletcher 1975).

In addition to macroorganisms, phlorotannins are also inhibitory to microorganisms. Conover \& Sieburth (1964) showed that Pseudomonas and Vibrio bacteria were sensitive to phlorotannins extracted from Sargassum natans and S. fluitans (see also Sieburth \& Conover 1965). The distribution of microorganisms on brown algal surface is suggested to be influenced by the gradient of phlorotannins concentration along the algal fronds (Conover \& Sieburth 1964, Sieburth \& Conover 1965, 1966, Seshadri \& Sieburth 1971).

There are reports showing that levels of macrofouling on algae, bryozoans (Al-Ogily \& Knight-Jones 1977), sponges (Thompson et al. 1985), and ascidians (Wahl et al. 1994) are inversely correlated with the antibacterial activity of secondary metabolites present in the organisms. Antibacterial activity of natural compounds may affect larval settlement of marine invertebrate by selective suppression of certain bacterial species of biofilms (Avelin et al. 1993, Walls et al. 1993). Bacteria affect larval settlement by exuding chemicals into the surrounding environment (Bryan et al. in press) and/or altering the environment of a surface by projection of extracellular domains which change the chemistry, charge, and free energy characteristics of the surface (Maki et al. 1989). The response of larvae to bacterial stimulation tends to be species-specific. Multiple species bacterial films developed naturally in the field and single strain bacterial films developed in the laboratory may enhance (Zobell \& Allen 1935, Kirchman et al. 1982, Mitchell \& Maki 1988, Hadfield et al. 1994), inhibit (Maki et al. 1988, Mitchell \& Maki 1988, Holmstrom et al. 1992) or not affect (Brancato \& Woollacott 1982) the settlement of marine invertebrate larvae. Therefore, alteration in species composition of a biofilm by selective suppression of one or several bacterial strains may change the overall stimulation of the biofilm to larvae and hence changes its attractiveness to competent larvae.

At a fish farm in Clear Water Bay, Hong Kong, the brown alga Sargassum tenerrimum exists in the vicinity of colonies of Hydroides elegans and other macrofoulers. S. tenerrimum, however, is rarely fouled (authors' pers, obs.). Recently, Walters et al. (1996) showed that the waterborne chemicals exuded by brown algae $S$. echinocarpum, $S$. polyphyllum, and Sphacelaria tribuloides reduced settlement of $H$. elegans larvae. Hadfield et al. (1994) also showed that $H$. elegans larvae required bacterial films to settle and that settlement was directly correlated with the density of short rod-shaped bacteria in natural bacterial films. This suggests a possible species-related settlement response of $H$. elegans larvae to bacteria.

Phloroglucinol and tannic acid, which are structurally related to phlorotannins, have also been suggested to be detrimental to both invertebrates and microorganisms (Sieburth \& Conover 1965, Targett \& Stochaj 1994). Phloroglucinol is the monomeric unit of phlorotannins while tannic acid consists of oligomers of phloroglucinol attaching to a glucose molecule. Phloroglucinol also exists in brown algae while tannic acid originates from terrestrial plants. We hypothesize that (1) phlorotannins, and the related compounds phloroglucinol and tannic acid, are inhibitory to Hydoides elegans larval settlement and are bacteriostatic, (2) the 3 compounds selectively inhibit certain bacteria, leading to changes in composition of the bacterial community, and (3) the altered bacterial community may not be attractive to $H$. elegans larval settlement. To test these hypotheses, we investigated (1) the toxicity and settlement inhibition effects of the phlorotannins, phloroglucinol, and tannic acid on $H$. elegans larvae, (2) the effects of the 3 compounds on the growth of bacteria, and (3) settlement of $H$. elegans larvae on both monospecies and multispecies bacterial films.

\section{MATERIALS AND METHODS}

Source of chemical compounds. The brown alga Sargassum tenerrimum was used as a natural source of phlorotannins. The algae were collected in a subtidal area near a fish farm in Clear Water Bay, Hong Kong $\left(22^{\circ} 19^{\prime} \mathrm{N}, 114^{\circ} 16^{\prime} \mathrm{E}\right)$. The algae were transported to the laboratory in seawater, then briefly rinsed in tap water and frozen immediately at $-80^{\circ} \mathrm{C}$ until needed for extraction of phlorotannins.

Phlorotannins were extracted from Sargassum tenerrimum following the procedures in Ragan \& Glombitza (1986). Briefly, freeze-dried algae were extracted twice in $70 \%$ methanol at $-20^{\circ} \mathrm{C}$ for $24 \mathrm{~h}$. This initial extract was filtered and methanol was removed by rotary evaporation. The aqueous portion was partitioned twice with hexane for $24 \mathrm{~h}$ to remove lipophilic substances. The aqueous phase was dialysed (molecular weight cut off at 3000 dalton) against distilled water to remove metal ions, carbohydrates, and amino acids (Yan 1994). The indialysable portion was concentrated by vacuum and stored in $1 \mathrm{ml}$ vials at $-80^{\circ} \mathrm{C}$. Concentration of phlorotannins was determined by the FolinDenis (1915) assay with phloroglucinol as the standard. Tannic acid (extra pure grade) and phloroglucinol (tis- 
sue culture gradel were obtained from RDH, Germany, and Sigma Chem. Co., USA, respectively.

Larval culture. Adult Hydroides elegans were obtained from submerged rafts at a fish farm in Clear Water Bay. Larvae were obtained and raised by procedures modified from Hadfield et al. (1994). Briefly, clean tubes of adult $H$. elegans were gently broken into two in a petri dish of $0.22 \mu \mathrm{m}$ filtered seawater (FSW). Newly released oocytes were transferred to $500 \mathrm{ml}$ of FSW and several drops of sperm suspension were added to the container. The FSW with sperms was decanted after 15 min and the fertilized eggs were transferred to a beaker containing 21 of FSW. After hatching, the larvae were fed Isochrysis galbana at a concentration of approximately $6 \times 10^{5}$ cells $\mathrm{ml}^{-1}$ (Bryan et al. 1997, Qiu \& Qian 1997). The culture was aerated and maintained at $28^{\circ} \mathrm{C}$ under a $15 \mathrm{~h}$ light: $9 \mathrm{~h}$ dark cycle. Competency of the larvae was tested on the fourth day after fertilization by transferring approximately 20 larvae to $5 \mathrm{ml}$ of $10^{-4} \mathrm{M}$ isobutylmethylxanthine (IBMX) in FSW (Bryan et al. 1997). Larvae displaying crawling behavior within $15 \mathrm{~min}$ of incubation were recorded as competent.

Isolation of bacteria from biofilm. Five sterilized glass slides were tied to a string and submerged in seawater at $1 \mathrm{~m}$ depth at the pier of the Hong Kong University of Science and Technology, Clear Water Bay, for development of natural biofilms. Slides to be deployed were sealed in a plastic bag and then submerged into the seawater to avoid contamination by bacteria at the water-air interface. The plastic bag was removed under water and the slides remained suspended for $24 \mathrm{~h}$. To retrieve the slides, they were sealed in a plastic bag underwater and transported to the laboratory in autoclaved FSW. The biofilm was scraped off the slides into autoclaved FSW with a sterilized paint brush and inoculated on nutrient agar plates prepared with FSW for growth of bacteria. After $24 \mathrm{~h}$ incubation at $30^{\circ} \mathrm{C}$, the bacterial colonies were screened according to their colony morphology, growth form in nutrient broth, cellular morphology, motility, gram stain property, and catalase and oxidase activities. Catalase and oxidase tests were conducted by methods modified from Smibert \& Krieg (1994). Briefly, the oxidase activity was determined by adding a few drops of $1 \%$ tetramethyl-pphenyldiamine in dimethylsulfoxide onto the bacterial colonies. A positive result was indicated by development of purple color. The catalase activity was determined by adding a few drops of $3 \%$ hydrogen peroxide onto the bacterial colonies. A positive result was indicated by production of bubbles. Bacterial strains with distinct characteristics were isolated and grown in nutrient broth as pure cultures. The broth cultures were mixed with the same volume of autoclaved glycerol and stored at $-80^{\circ} \mathrm{C}$ in $1 \mathrm{ml}$ aliquots.
Toxicity assay. Series of solutions of test compounds at $1 / 2 \log$ intervals were prepared freshly in FSW. FSW without added substance served as a control. Twenty competent larvae were introduced into each petri dish containing $5 \mathrm{ml}$ of test solution and were incubated at $28^{\circ} \mathrm{C}$. Survivorship was determined after $48 \mathrm{~h}$ of incubation. Larvae that were actively swimming or with intact body were recorded as alive. Six replicates were used in each concentration and data collected from all concentrations were examined by probit analysis. Toxicity was expressed as $48 \mathrm{~h} \mathrm{LC}_{50}$ (the concentration leading to $50 \%$ mortality compared to the control) with a $95 \%$ confidence interval.

Settlement inhibition assay. Since Hydroides elegans larvae do not settle until a proper cue is provided (Hadfield et al. 1994, Bryan et al. 1997), IBMX was used as settlement inducer (Bryan et al. 1997). Serial dilutions of test compounds at $1 / 2 \log$ intervals were made in $10^{-4} \mathrm{M}$ solution of IBMX in FSW. Dishes containing $10^{-4} \mathrm{M}$ of IBMX in FSW served as a control. Twenty larvae were introduced into each polystyrene petri dish (Falcon \#1006) with $5 \mathrm{ml}$ of test solution and were incubated at $28^{\circ} \mathrm{C}$ for $48 \mathrm{~h}$. After incubation, the dishes were examined for metamorphosed individuals which had calcified tubes and tentacles. Six replicates were used in each concentration and data collected from all concentrations were examined by probit

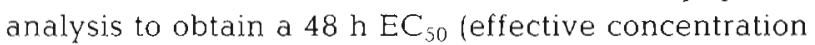
corresponding to $50 \%$ of settlement in the control) with a $95 \%$ confidence interval.

Antibacterial assay. The 3 compounds were dissolved in methanol and $1 \mathrm{mg}$ of each compound was applied individually onto $6 \mathrm{~mm}$ diameter circular discs of sterilized filter paper (Whatman No. 1). The filter paper discs were air dried and then put onto nutrient agar inoculated with a bacterial lawn. Additional set of filter paper discs with methanol, applied and dried, served as control. The setup was incubated for $24 \mathrm{~h}$ at $30^{\circ} \mathrm{C}$, after which the radius of the no bacterial growth zone around each disc was measured.

Larval settlement on bacterial films. The assay of larval settlement on bacterial films was divided into 2 parts: (1) settlement on monospecies films to probe the species specificity of bacteria-larvae interaction; (2) settlement on multispecies bacterial films to study the effects of alteration in the bacterial community composition on larval settlement. Bacterial films were developed according to a method modified from Maki et al. (1988). Bacterial cells were harvested from $48 \mathrm{~h}$ broth cultures by centrifugation at $8000 \mathrm{rpm}(7741 \times \mathrm{g})$ for $10 \mathrm{~min}$. The bacterial cell pellets were resuspended in autoclaved FSW. Six milliliters of the bacterial suspension containing either 1 or more than 1 species of bacteria were introduced into polystyrene petri dishes (Falcon \#1006) and incubated at room temperature to 
allow the bacterial cells to attach onto the dish surface. After incubation, the dishes were emptied and dipped 5 times into $500 \mathrm{ml}$ of autoclaved FSW to remove unattached cells. Five milliliters of autoclaved FSW and 20 larvae were then added to each dish. Petri dishes without bacterial films and dishes coated with 24 h old natural biofilm (NBF) both served as controls. Metamorphosed larvae were counted after $48 \mathrm{~h}$. Bacteria attached to a petri dish were stained with acridine orange according to procedures in (Daley \& Hobbie 1975) and the density was determined by epifluorescence microscopy at $1000 \times$ magnification.

The experiment investigating larval settlement on monospecies bacterial films was repeated 3 times with 6 replicates of each treatment each time. Data were arcsine-transformed and the mean percentages of metamorphosed larvae on films of each bacterial species were compared against NBF control by Dunnett's multiple comparison test. In order to improve arcsine transformation, a value of $1 / 4 \mathrm{n}$ was given to the replicates in which no larvae metamorphosed (Zar 1996).

To test the hypothesis that an alteration in natural biofilm may affect larval settlement, the bacterial strains that resulted in percentage metamorphosis consistently differing from the NBF control were selected for the assay of larval settlement on multispecies film. Suspensions of each of the selected bacterial strains were initially mixed with each of the other selected bacterial strains in a 1:1 ratio to allow development of the multispecies bacterial films. Mixing of bacterial suspensions in other ratios was done when necessary. Six replicates were used in each treatment. Data obtained were arcsine-transformed and analyzed by Tukey's test (Zar 1996).
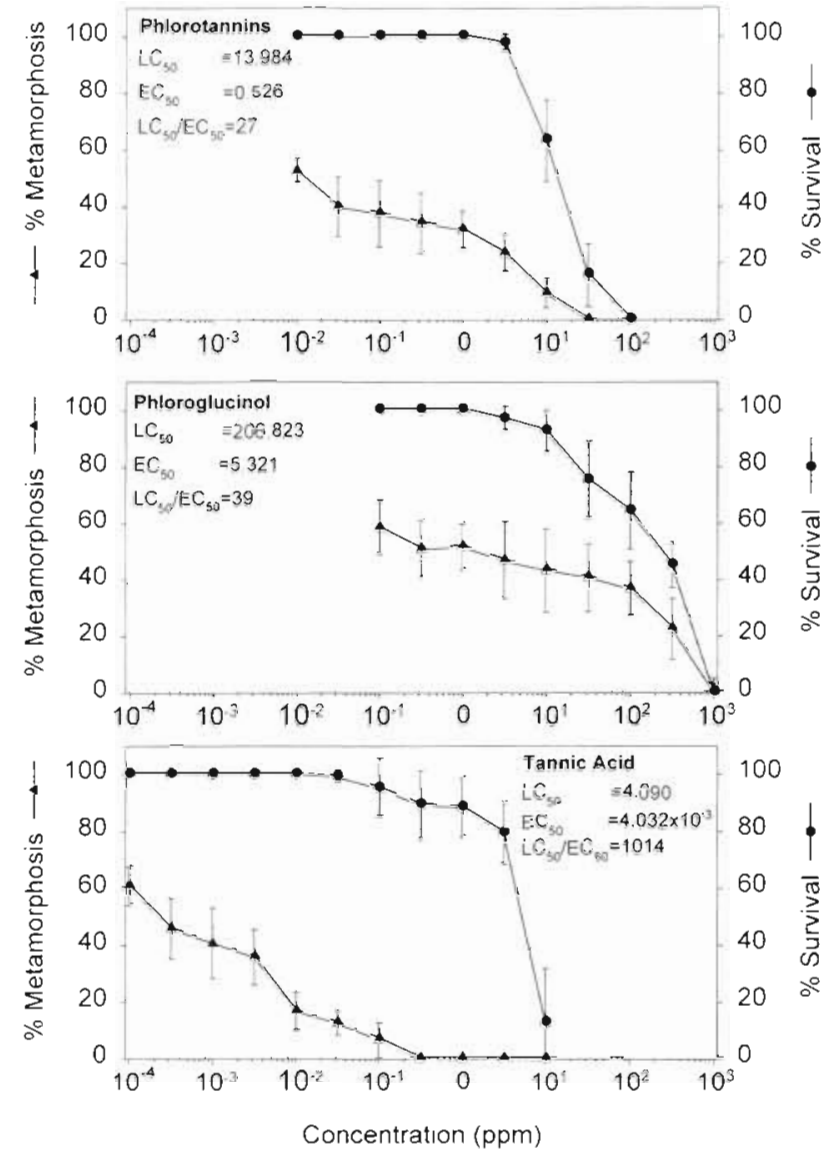

Fig. 1. Hydroides elegans. Toxicity and settlement inhibition effects of phlorotannins, phloroglucinol and tannic acid on larvae. Toxicity and settlement inhibition are expressed as $48 \mathrm{~h} \mathrm{LC}_{50}$ and $48 \mathrm{~h} \mathrm{EC}_{50}$ respectively. The ratio $\mathrm{LC}_{50} / \mathrm{EC}_{50}$ indicates the relative effectiveness of the compound. An effective non-toxic antifouling compounds should have a high $\mathrm{LC}_{50} / \mathrm{EC}_{50}$ ratio

Table 1. Morphological and biochemical characteristics of bacteria isolated from natural biofilm. Diameters of colony were measured after $24 \mathrm{~h}$ growth on nutrient agar at $30^{\circ} \mathrm{C}$. Flocculent form of growth refers to bacteria that aggregate to a woolly appearance in the broth, while membranous refers to the formation of a thin membrane that suspends in broth. In motility, Gram stain property, and catalase and oxidase tests ' + ' indicates, motile, Gram-positive, positive to catalase or oxidase test; '-' indicates nonmotile. Gram-negative, or negative to catalase or oxidase test

\begin{tabular}{|c|c|c|c|c|c|c|c|c|c|}
\hline \multirow[t]{2}{*}{ Bacteria \# } & \multicolumn{3}{|c|}{ Colony morphology } & \multirow{2}{*}{$\begin{array}{c}\text { Growth in } \\
\text { marine } \\
\text { broth }\end{array}$} & \multirow{2}{*}{$\begin{array}{l}\text { Gram } \\
\text { stain }\end{array}$} & \multirow{2}{*}{$\begin{array}{c}\text { Cell } \\
\text { shape }\end{array}$} & \multirow[t]{2}{*}{ Motility } & \multirow[t]{2}{*}{ Catalase } & \multirow[t]{2}{*}{ Oxidase } \\
\hline & Color & Shape & $\begin{array}{c}\text { Diameter } \\
\text { (mm) }\end{array}$ & & & & & & \\
\hline 1 & Light brown & Circular & 1 & Flocculent & - & Short rod & + & + & + \\
\hline 2 & Light brown & Circular & 1.5 & Flocculent & - & Short rod & + & + & + \\
\hline 3 & Brown & Circular & 1.5 & Flocculent & - & Short rod & + & + & + \\
\hline 4 & White & Circular & 1 & Membranous & - & Cocci & - & + & - \\
\hline 5 & Brown & Circular & 1 & Membranous & - & Cocci & - & + & - \\
\hline 6 & Green & Circular & 0.5 & Membranous & - & Cocci & - & + & - \\
\hline 7 & White & Irregular & $>5$ & Flocculent & - & Short rod & + (swarmer) & + & + \\
\hline 8 & White & Irregular & $>5$ & Flocculent & - & Short rod & + (swarmer) & - & + \\
\hline 9 & Orange & Circular & 1 & Membranous & & Long rod & - & + & + \\
\hline 10 & Colourless & Circular & 3.5 & Membranous & - & Short rod & - & + & + \\
\hline 11 & Colourless & Circular & 1.5 & Membranous & - & Short rod & + & + & + \\
\hline 12 & White & Circular & 1 & Membranous & - & Short rod & + & + & + \\
\hline
\end{tabular}




\section{RESULTS}

\section{Toxic and settlement inhibition assays}

The compounds phlorotannins, phloroglucinol, and tannic acid showed various levels of toxicity and settlement inhibition effects (Fig. 1). Phlorotannins showed $\mathrm{EC}_{50}$ and $\mathrm{LC}_{50}$ at $0.526 \mathrm{ppm}$ and $13.984 \mathrm{ppm}$, respectively. Thus the $\mathrm{LC}_{50}$ of phlorotannins was 27 times higher than the $\mathrm{EC}_{50}$. Phloroglucinol inhibited $50 \%$ of larval settlement at $5.321 \mathrm{ppm}$ and killed $50 \%$ of larvae at $206.823 \mathrm{ppm}$, which was 39 times higher. Tannic acid was the most toxic compound as well as the most potent settlement inhibitor; its $\mathrm{EC}_{50}$ and $\mathrm{LC}_{50}$ were $4.032 \times$ $10^{-3} \mathrm{ppm}$ and $4.090 \mathrm{ppm}$, respectively. The $\mathrm{LC}_{50}$ of tannic acid was 1014 times higher than the $\mathrm{EC}_{50}$.

\section{Isolation of bacteria from natural biofilm}

Based on morphological characteristics and simple biochemical tests, 12 different types of bacteria (named B1 to B12; see Table 1) were isolated from a $24 \mathrm{~h}$ old natural biofilm. All 12 bacteria were Gramnegative; 9 of them were rod-shaped and the rest were cocci-shaped. Seven bacteria were motile with 2 showing swarming behavior. The bacterial colonies displayed various colors such as brown, white, green, orange and colourless. The colonies of the swarming bacteria were irregular in shape while the rest of the bacteria were circular. Five of the bacteria displayed a flocculent form in marine broth while the rest displayed a membranous form. Eleven bacteria were positive in the catalase test and 9 bacteria were positive in the oxidase test (Table 1).

\section{Antibacterial assay}

Antibiosis activities of the test compounds were determined by the size of clear zones around the discs (Table 2). Tannic acid was the most potent antibiotic among the 3 tested compounds, inhibiting the growth of 8 species of bacteria at a dose of $1 \mathrm{mg} \mathrm{disc}^{-1}$. At the same dosage, both phlorotannins and phloroglucinol arrested the growth of 4 species of bacteria. Phloroglucinol produced only very small inhibition zones $(0.1$ to $0.2 \mathrm{~mm})$ while tannic acid produced inhibition zones as large as those produced by penicillin and streptomycin. Most of the bacterial species were sensitive to both commercial antibiotics, with the exception of species B7, B8 and B11 In contrast, only bacterium B11 was sensitive to all 3 phenolics. All other bacteria were sensitive to only 1 or 2 phenolics.

\section{Larval settlement on monospecies bacterial films}

In all 3 experiments, settlement of Hydroides elegans larvae differed among species of bacteria and the same species of bacterium caused different levels of settlement among individual experiments (Fig. 2). Bacteria B2, B6, B9 and B12 always caused significantly different levels of metamorphosis compared to the NBF control. Among them, larval metamorphosis on bacterial films of B2 and B6 was significantly lower than NBF while metamorphosis on bacterial films of B9 and B12 was significantly higher than NBF. Epifluorescence microscopy revealed that the bacterial densities on experimental dishes ranged from $0.760 \times 10^{6}$ to $3.028 \times 10^{6}$ cells $\mathrm{cm}^{-2}$ (Table 3 ). There was no significant correlation between bacterial cell densities of the 12 tested bacterial strains and percentage metamorphosis $\left(p=0.833, r^{2}=0.005\right)$.

\section{Larval settlement on multispecies bacterial films}

Effects of alteration of bacterial community composition were investigated by selective mixing of different bacterial strains for bacterial film development. Since bacteria B2, B6, B9 and B12 consistently caused significantly different levels of metamorphosis than the NBF control in the monospecies bacterial film experiment,

Table 2. Inhibition of bacterial growth by phlorotannins, phloroglucinol and tannic acid. Two commercial antibiotics, penicillin and streptomycin, were included as controls. Antibacterial effects of the compounds are expressed by the radius of zone of inhibitions after $24 \mathrm{~h}$ incubation. '-' indicates no zone of inhibition was formed

\begin{tabular}{|c|c|c|c|c|c|}
\hline \multirow[t]{2}{*}{ Bacteria \# } & \multicolumn{5}{|c|}{ Zone of inhibition at dose $1 \mathrm{mg}$ (mm of radius) } \\
\hline & $\begin{array}{l}\text { Phloro- } \\
\text { tannins }\end{array}$ & $\begin{array}{l}\text { Phloro- } \\
\text { glucinol }\end{array}$ & $\begin{array}{c}\text { Tannic } \\
\text { acid }\end{array}$ & Penicillin & $\begin{array}{l}\text { Strepto- } \\
\text { mycin }\end{array}$ \\
\hline 1 & - & - & 10 & 9 & 9 \\
\hline 2 & - & - & $\cdot 9$ & 10 & 9 \\
\hline 3 & - & - & - & 8.5 & 9 \\
\hline 4 & - & - & 3 & 8 & 10 \\
\hline 5 & - & 0.2 & - & 7 & 7.5 \\
\hline 6 & - & 0.1 & - & 9 & 6.5 \\
\hline 7 & - & - & 7 & - & 9.5 \\
\hline 8 & 7 & - & 4.5 & - & 10 \\
\hline 9 & 6.5 & - & 20 & 10 & 28 \\
\hline 10 & 2 & - & 2 & 11 & 9.5 \\
\hline 11 & 3 & 0.2 & 3.5 & - & - \\
\hline 12 & - & 0.1 & - & 9 & 8 \\
\hline
\end{tabular}



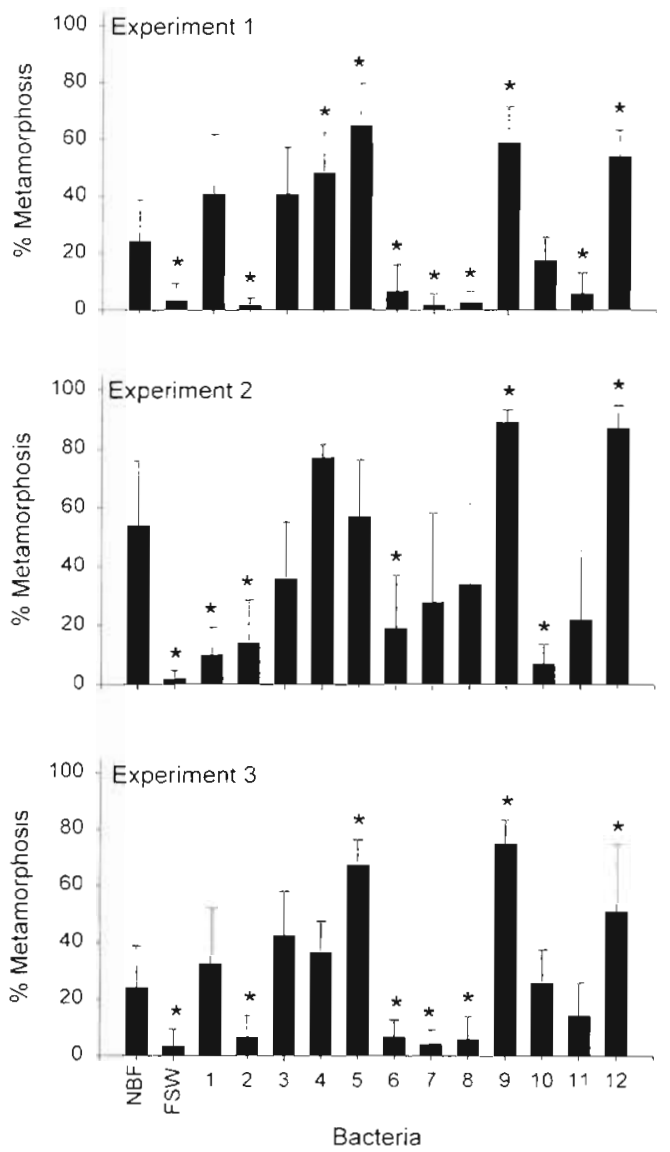

Fig. 2. Hydroides elegans. Larval metamorphosis in response to bacterial isolates after $48 \mathrm{~h}$ of incubation. The assay was done in triplicate and denoted as Expts 1,2 and 3. The numbers on the $x$-axis correspond to the identities of the bacteria. Control dishes coated with $24 \mathrm{~h}$ old natural biofilm and control dishes without bacteria are indicated as NBF and FSW respectively. ${ }^{*}$ Data is significantly different from NBF control

they were chosen to investigate the effects of multispecies bacterial films on Hydroides elegans larval settlement. When each bacterial species was mixed with another at a 1:1 ratio, different levels of metamorphosis were obtained (Fig 3). Monospecies films of bacteria B2 and B6 caused similar levels of metamorphosis as well as the bacterial film obtained by combining both B2 and B6 (ANOVA: $p=0.284$ ) (Fig. 3a). Similar results were obtained in the experiments with bacteria B9 and B12 (Fig. 3b), in which no significant differences were seen between monospecies films of B6 and B9 or between the multispecies films consisting of $B 9$ and B12 (ANOVA: $p=0.122$ ). When $B 6$ was mixed with $B 9$ or $\mathrm{B} 12$, percentage metamorphosis on multispecies films was always lower than on 89 or B12 monospecies film but not different from B6 alone (Fig. 3c, d). In the case of multispecies films consisting of bacteria B2 with
B9 or B12, percentage metamorphosis on the multispecies films was always higher than the monospecies films of B2 but not different from B9 or B12 (Fig. 3e, f).

A further assay was done to demonstrate the effects of alteration in the ratio of different bacterial species in the bacterial films. Bacteria B2 was mixed with B9 or $B 12$ in the ratios of $1: 1,3: 1$ and $7: 1$. The results show that at the mixing ratio of $1: 1$ of $\mathrm{B} 2$ and $\mathrm{B} 12$, the resulting film was not different from the monospecies film of B12 (Fig. 4a). However, B12 started to lose its effect when the ratio of $\mathrm{B} 2$ and $\mathrm{B} 12$ increased to $3: 1$ and $7: 1$ When $B 2$ was mixed with $B 9$, at all mixing ratios $(1: 1$, 3:1 and 7:1), settlement on the resultant films were not significantly different from settlement on monospecies films of either B2 and B9 (Fig. 4b).

\section{DISCUSSION}

Two mechanisms have been proposed for the antifouling effects of natural compounds: natural compounds may directly inhibit the settlement and/or survival of the larvae of macrofoulers, or natural compounds may regulate the growth of microfoulers, such as bacteria, which in turn affects larval settlement of the macrofoulers (Avelin et al. 1993). The former mechanism acts by creating a toxic or unfavorable

Table 3. Attachment of bacteria on Falcon \#1006 polystyrene petri dish. Data of bacteria density and percentage larvae metamorphosed were taken from Expt 1 of settlement and metamorphosis of Hydroides elegans larvae on monospecies bacterial films. Blank control is dish without treatment of bacteria while NBF control is dish coated with $24 \mathrm{~h}$ old natural biofilm. Mean density of bacteria was based on counts of 5 fields at $1000 \times$ magnification under epifluorescence microscope. There is no correlation between bacterial density and percentage larval metamorphosis $(\mathrm{p}=0.8325)$

\begin{tabular}{|ccc|}
\hline Bacteria \# & $\begin{array}{c}\text { Mean density } \\
\text { of bacteria } \\
\times 10^{4} \text { cells } \\
\mathrm{cm}^{-2}( \pm \mathrm{SD})\end{array}$ & $\begin{array}{c}\text { Mean \% larvae } \\
\text { metamorphosed } \\
( \pm \mathrm{SD})\end{array}$ \\
\hline Blank control & 0 & $3.333(6.055)$ \\
NBF control & $7.600(1.673)$ & $24.167(14.634)$ \\
1 & $106.400(6.025)$ & $40.833(20.837)$ \\
2 & $302.800(41.324)$ & $1.667(2.582)$ \\
3 & $168.400(19.217)$ & $40.833(16.253)$ \\
4 & $163.600(13.164)$ & $48.333(14.024)$ \\
5 & $240.600(29.048)$ & $65.000(14.832)$ \\
6 & $127.000(19.196)$ & $6.667(9.309)$ \\
7 & $100.000(15.476)$ & $1.667(4.082)$ \\
8 & $76.000(18.358)$ & $2.500(4.183)$ \\
9 & $187.400(22.777)$ & $59.167(12.416)$ \\
10 & $160.800(40.059)$ & $17.500(8.216)$ \\
11 & $279.400(30.262)$ & $5.833(7.360)$ \\
12 & $53.600(11.866)$ & $54.167(9.174)$ \\
\hline
\end{tabular}



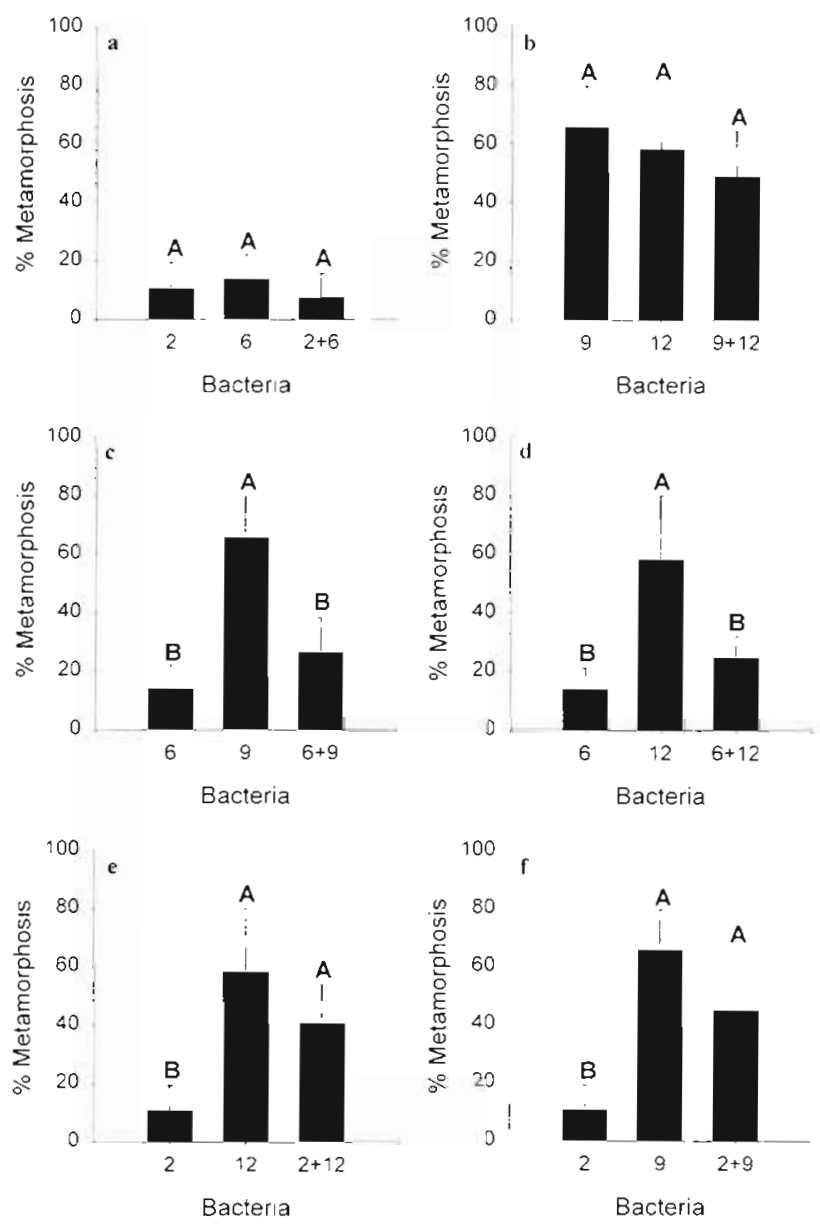

Fig. 3. Hydroides elegans. Larval metamorphosis in response to multispecies bacterial films after $48 \mathrm{~h}$ of incubation. The numbers on the $x$-axis correspond to the identities of the bacteria. Monospecies bacterial films were used as controls. Multispecies bacterial films were developed from mixing suspensions of 2 bacterial species in a 1:1 ratio. Data with significant difference are indicated by different letters above the bars

environment immediately above the surface while the latter is suggested to be due to a species-related interaction between bacteria and larvae and is a result of selective suppression of bacterial species in biofilms. Our results suggest that phlorotannins, phloroglucinol, and tannic acid may inhibit Hydroides elegans larval settlement by both mechanisms.

Our toxicity and settlement inhibition assay revealed that phlorotannins, phloroglucinol, and tannic acid varied in effectiveness to a great extent, even though they are structurally similar compounds. Low $\mathrm{EC}_{50}$ values of the 3 compounds, in particular tannic acid, suggest that they are potent settlement inhibitors. The $\mathrm{LC}_{50}$ values suggest that phlorotannins and tannic acid are similar in toxicity while phloroglucinol is the least toxic compound. A comparison of $\mathrm{LC}_{50}$ and $\mathrm{EC}_{50}$ values provides insight to the possible working mechanisms
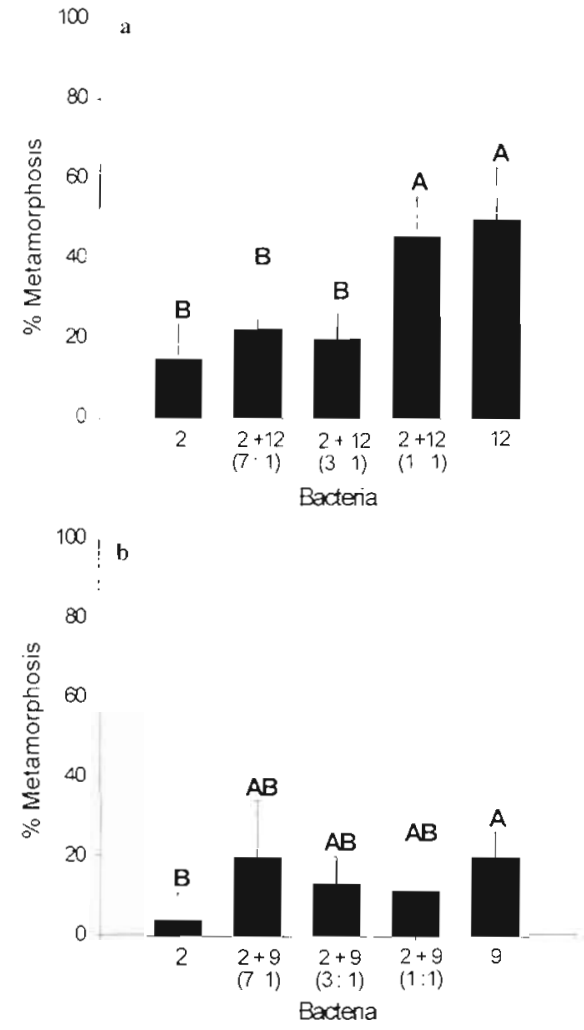

Fig. 4. Hydroides elegans. Larval metamorphosis in response to multispecies bacterial films after $48 \mathrm{~h}$ of incubation. Monospecies bactenal films were used as controls. The bacterial films were developed by mixing suspensions of 2 bacterial species in various ratios as shown in parentheses. Data with significant difference are indicated by different letters above the bars

of the compounds under investigation. A compound that has a high $\mathrm{LC}_{50} / \mathrm{EC}_{50}$ ratio is suggested to inhibit larval settlement by a non-toxic mechanism as a high $\mathrm{LC}_{50} / \mathrm{EC}_{50}$ ratio indicates that the toxic concentration is much higher than the concentration required to inhibit larval settlement (Rittschof et al. 1992). In contrast, a compound that inhibits larval settlement by a toxic mechanism should have a low $\mathrm{LC}_{50} / \mathrm{EC}_{50}$ ratio (Rittschof et al. 1992), which indicates that the effective concentration for settlement inhibition is close to the toxic concentration. Although tannic acid is the most toxic compound, its high $\mathrm{LC}_{50} / \mathrm{EC}_{50}$ ratio suggests that it inhibits Hydroides elegans larval settlement most likely by means of a non-toxic mechanism while the low $\mathrm{LC}_{50} / \mathrm{EC}_{50}$ ratio of phloroglucinol suggests that it inhibits $H$. elegans larval settlement in a relatively toxic way even though it is the least toxic compound.

The results from the assay of larval settlement on monospecies bacterial films showed that different strains of bacteria caused different levels of Hydroides elegans larval settlement. In the other words, the settlement of $H$. elegans larvae may be dependent on the 
bacterial species to which the larvae are exposed. Enumeration of bacterial density on the test substrata revealed that such distinctive responses of larvae were not due to differences in bacterial density. The variation of results among the 3 replicated experiments may be due to variation in physiological conditions of either bacteria and/or the larvae. A comparison of larval settlement on monospecies bacterial films to that on natural biofilms revealed that some bacteria induced higher levels of settlement than natural biofilms (NBF) while some other bacteria induced lower levels. Therefore, we suggest that the induction of settlement by a natural biofilm is a combined effect of different species of bacteria in the natural biofilm.

The assay of larval settlement on multispecies bacterial films revealed that both qualitative and quantitative changes in species composition of multispecies bacterial films affected Hydroides elegans larval settlement. When 2 bacteria with similar effects (cause similar levels of metamorphosis) were mixed (e.g. bacteria $\mathrm{B} 2$ and $\mathrm{B} 6$, or $\mathrm{B} 9$ and B12), the resultant films were not different from the corresponding monospecies films. When two bacteria with different effects (cause different levels of metamorphosis) were mixed, the effects were antagonistic and dependent on the bacterial species and the mixing ratio. For instance, bacteria $\mathrm{B} 6$ exerted a relatively strong effect, overriding $\mathrm{B} 9$ and $\mathrm{B} 12$, while a high proportion of $\mathrm{B} 2$ in bacterial films could not override the effect of low proportion of B9. Our experimental model mimicked the simplest community, which consisted of only 2 species of bacteria, and the results showed that the settlement of $H$. elegans larvae on multispecies films was dependent on the species composition of the bacterial films. Either a qualitative or a quantitative change in the species composition of bacterial films affects settlement of $H$. elegans larvae.

An integration of larval settlement data with the results from the antibacterial assays showed that some of the bacteria (e.g. B9) that were sensitive to the phenolic compounds induced high levels of metamorphosis. However, some of bacteria (e.g. B6) that were resistant to the phenolics were, in fact, inducing very low levels of larval settlement. Therefore, we speculate that bacteria that induce a high level of larval settlement (e.g. bacteria B9 in this study) may be lacking in a biofilm that is developed under the influence of the phenolic compounds and the niches are available to phenolic-resistant bacteria that cause low levels of Hydroides elegans larval settlement. As a result, the phenolic-treated biofilm may become unfavorable to $H$. elegans larval settlement.

A dynamic model of fouling process as suggested by Roberts et al. (1991) states that the colonization of a surface by bacteria and invertebrate larvae does not necessarily follow the chronological sequence (bacteria precede larvae) that was previously suggested (Davis et al. 1989). In fact, the interactions between bacteria, invertebrate larvae, and other fouling components are dynamic and the existence of fouling components in the biofouling layer can be independent of each other. Therefore, a successful solution to biofouling problems requires mechanisms that act simultaneously on different components of fouling (Clare et al. 1992). We suggest that natural compounds such as the phenolic compounds, which are capable of targeting both larvae and bacteria, may be effective antifoulants against fouling species such as Hydroides elegans that require biofilms for settlement.

Acknowledgements. The authors thank $M$. Hadfield and D Rittschof for suggestions about experimental procedures. The authors also extend thanks to L. Gosselin and L. McEdward as well as 4 anonymous referees for comments on the manuscript. This study was supported by a RGC (HKUST 651/96M) grant to P.Y.Q.

\section{LITERATURE CITED}

Al-Ogily SM, Knight-Jones EW (1977) Antifouling role of antibiotics produced by marine algae and bryozoans Nature 265:728-729

Avelin $\mathrm{M} \mathrm{Sr}$, Vitalina M Sr, Rittschof D, Nagabhushanam R (1993) Bacterial-barnacle interaction: potential of using juncellins and antibiotics to alter structure of bacterial communities. J Chem Ecol 19(10):2155-2167

Brancato MS, Woollacott RM (1982) Effect of microbial films on settlement of bryozoan larave (Bugula simplex, $B$. stolonifera and B. turrita). Mar Biol 71:51-56

Bryan JP, Kreider JL, Qian PY (in press) Settlement of the serpulid polychaete Hydroides elegans on the arborescent bryozoan Bugula neritina: evidence of a chemically mediated relationship. J Exp Mar Biol Ecol

Bryan PJ, Qian PY, Kreider JL, Chia FS (1997) Induction of larval settlement by pharmacological and conspecific associated compounds in the serpulid polychaete Hydroides elegans. Mar Ecol Prog Ser 146:81-90

Clare AS, Rittschof D, Gerhart DJ, Maki JS (1992) Molecular approaches to nontoxic antifouling. Invert Reprod Dev 22: $67-76$

Conover JT, Sieburth JMCN (1964) Effect of Sargassum distribution on its epibiota and antibacterial activity. Bot Mar 6: $147-157$

Conover JT, Sieburth J McN (1966) Effect of tannins excreted from Phaeophyta on planktonic animal survival in tide pools. Proc Int Seaweed Symp 5:99-100

Daley RJ, Hobbie JE (1975) Direct counts of aquatic bacteria by a modified epifluorescence technique. Limnol Oceanogr 20:875-882

Davis AR, Targett NM, MCConnell OJ, Young CM (1989) Epibiosis of marine algae and benthic invertebrates: natural products chemistry and the mechanisms inhibiting settlement and overgrowth. In: Scheuer PJ (ed) Marine bioorganic chemistry, Vol 3. Springer-Verlag, Berlin, p 85-114

De Nys R, Steinberg PD, Willemsen P. Dworjanyn SA, Gabelish CL, King RJ (1995) Broad spectrum effects of secondary metabolites from the red alga Delisea pulchra in antifouling assays. Biofouling 8:259-271 
Fletcher RL (1975) Heteroantagonism observed in mixed algal cultures. Nature 253:534-535

Folin O, Denis W (1915) A colormetric method for the determination of phenols (and phenol derivatives) in urine. J Biol Chem 22:305-308

Hadfield MG, Unabia CC, Smith CM, Michael TM (1994) Settlement preferences of the ubiquitous fouler Hydroides elegans. In: Thompson MF, Nagabhushanam R, Sarojini R, Fingerman $M$ (eds) Recent developments in biofouling control. Balkema, Rotterdam, p 65-74

Holmstrom C, Rittschof D, Kjelleberg $S$ (1992) Inhibition of settlement by larvae of Balanus amphritie and Ciona intestinalis by a surface colonizing marine bacterium. Appl Environ Microbiol 58:2111-2115

Kirchman D, Graham S (1982) Bacteria induce settlement and metamorphosis of Janua (Dexiospira) brasiliensis Grube (Polychaeta: Spirorbidae). J Exp Mar Biol Ecol 56:153-163

Maki JS, Rittschof D. Costlow JD, Mitchell R (1988) Inhibition of attachment of larval barnacles, Balanus amphitrite, by bacterial surface films. Mar Biol 97:199-206

Maki JS, Rittschof D, Schmidt AR, Snyder AG, Mitchell R (1989) Factors controlling attachment of bryozoan larvae: a comparison of bacterial films and unfilmed surfaces. Biol Bull (Woods Hole) 177:295-302

Mitchell R, Maki JS (1988) Microbial surface films and their influence on larval settlement and metamorphosis in the marine environment. In: Thompson MF, Sarjoini $R_{1}$ Nagabhushanam R (eds) Marine biodeterioration. Balkema, Rotterdam, p 489-497

Qiu JW, Qian PY (1997) The combined effects of salinity, temperature and food on early development of the polychaete Hydroides elegans. Mar Ecol Prog Ser 152:79-88

Ragan MA, Glombitza KW (1986) Phlorotannins, brown algal polyphenols. Prog Phycol Res 4:129-241

Rittschof D, Clare AS, Gerhart DJ, Avelin M Sr, Bonaventura $\mathrm{J}$ (1992) Barnacle in vitro assays for biologically active substances: toxicity and settlement inhibition assays using mass cultured Balanus amphitrite amphitrite Darwin. Biofouling $6: 115-122$

Roberts D, Rittschof D, Holm E, Schmidt AR (1991) Factors

Editorial responsibility: Otto Kinne (Editor),

Oldendorf/Luhe, Germany influencing larval settlement: temporal, spatial and molecular components of initial colonization. J Exp Mar Biol Ecol 150:203-221

Sieburth JMcN, Conover JT (1965) Sargassum tannins, an antibiotic which retards fouling. Nature 208:52-53

Sieburth IMCN, Conover JT (1966) Antifouling in Sargassum. natans: re-recognition of tannins activity. Proc lnt Seaweed Symp 5:207

Seshadri R, Sieburth JMcN (1971) Cultural estimation of yeasts on seaweeds. Appl Microbiol 22:507-512

Smibert RM, Krieg NR (1994) Phenotypic characterization. In Gerhardt P (ed) Methods for general and molecular baceriology. American Society for Microbiology, Washington, DC, p $607-654$

Targett NM, Stochaj WR (1994) Natural antifoulants and their analogs: applying nature's defense strategies to problems of biofouling control. In: Thompson MF. Nagabhushanam $R$, Sarojini R, Fingerman $M$ (eds) Recent developments in biofouling control. Balkema, Rotterdam, p 222-227

Thompson JE, Walker RP, Faulkner DJ (1985) Screening and bioassays for biologically-active substances from forty marine sponge species from San Diego, California, USA. Mar Biol 88:11-21

Wahl M, Jensen PR, William F (1994) Chemical control of bacterial epibiosis on ascidians. Mar Ecol Prog Ser 110:45-57

Walls JT, Ritz DA, Blackman AJ (1993) Fouling, surface bacteria and antibacterial agents of four bryozoan species found in Tasmania, Australia. J Exp Mar Biol Ecol 169:1-13

Walters LJ, Hadfield MG, Smith CM (1996) Waterborne chemical compounds in tropical macroalgae: positive and negative cues for larval settlement. Mar Biol 126:383-393

Yan XJ (1994) Studies on compositional and structural characteristics of phlorotannins and its interaction with alginate. $\mathrm{PhD}$ dissertation, Institute of Oceanology, Chinese Academy of Science Qingdao, China, p 26-29

Zar JH (1996) Biostatisitical analysis, 3rd edn. Prentice Hall International, Englewood Cliffs, NJ

Zobell CE, Allen EC (1935) The significance of marine bacteria in the fouling of submerged surfaces. J Bacteriol 29(3): $239-251$

Submitted: June 3, 1997; Accepted: October 8, 1997 Proofs received from author(s): November 20, 1997 